\title{
The clinical value of leucocyte count and neutrophil percentage in diagnosing uncomplicated (simple) appendicitis and predicting complicated appendicitis
}

\author{
Nuri Alper Şahbaz, M.D., Orhan Bat, M.D., Bülent Kaya, M.D., Suat Can Ulukent, M.D., \\ Özer İlkgül, M.D., Mehmet Yiğit Özgün, M.D., Özlem Akça, M.D.
}

Department of General Surgery, Kanuni Sultan Süleyman Training and Research Hospital, İstanbul

\begin{abstract}
BACKGROUND: The aim of this study was to establish the diagnostic value of leucocyte count and neutrophil percentage in both diagnosing simple appendicitis and predicting complicated appendicitis.

METHODS: The patients who underwent appendectomy with a clinical diagnosis of acute appendicitis (AA) between January $20 \mathrm{II}$ and December 2012 were studied retrospectively. The data of total WBC count, neutrophil ratio, and physical findings were analyzed. Sensitivities and specificities of leucocyte count and neutrophil ratio were calculated.

RESULTS: One hundred and fifty-nine patients, diagnosed with acute appendicitis, were operated. Simple appendicitis was detected in $\mathbf{8 2 . 4 \%}$ of the patients and complicated appendicitis in $17.6 \%$. Leucocyte count had low sensitivity and specificity for diagnosing acute appendicitis (67.5\% and $36.3 \%$, respectively). Neutrophil ratio had a sensitivity rate of $60.1 \%$ and specificity rate of $90.9 \%$. Complicated appendicitis was more common in male patients. Leucocyte count was statistically higher in patients with complicated appendicitis.
\end{abstract}

CONCLUSION: Two inflammatory markers, leucocyte count and neutrophil ratio, were evaluated for diagnosing acute appendicitis. Neutrophil ratio had higher sensitivity and specificity for acute appendicitis. On the other hand, increased leucocyte count and male gender was found to be a risk factor for complicated appendicitis.

Key words: Appendicitis; leucocyte; neutrophil count.

\section{INTRODUCTION}

Appendicitis is the most common acute surgical disease of the abdomen. Patients with acute appendicitis usually present with typical abdominal pain and physical findings include right lower quadrant tenderness, rebound tenderness, and muscle guarding. The clinical diagnosis of acute appendicitis (AA) can be difficult especially in females of child bearing age, children and the elderly. Negative appendectomy rates may reach up to 20 to $30 \%$. ${ }^{[1]}$

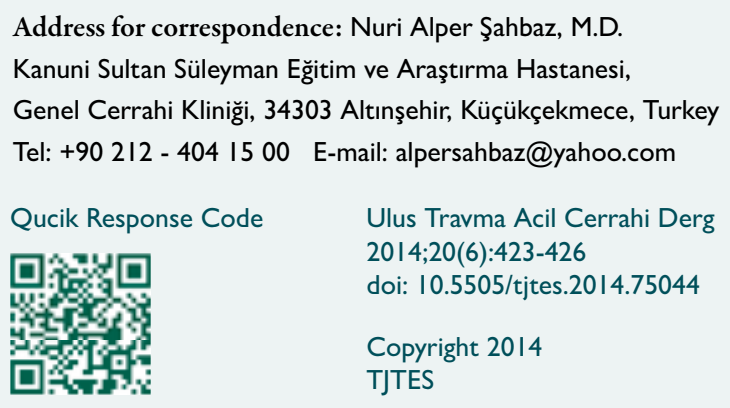

Complicated acute appendicitis, (perforation, gangrenous appendicitis, intraabdominal abscess, plastron formation and generalized peritonitis) may be detected in 20 to $30 \%$ of all appendicitis patients. ${ }^{[2]}$ It is related with increased risk of morbidity and mortality. Complicated appendicitis is associated with increased rate of wound infection, intraabdominal abscess, and postoperative ileus. Due to these serious problems, early diagnosis of appendicitis is mandatory in order to prevent these complications.

The aim of this study was to establish the diagnostic value of leucocyte count and neutrophil percentage in both diagnosing simple appendicitis and predicting complicated appendicitis.

\section{MATERIALS AND METHODS}

The patients who underwent appendectomy with a clinical diagnosis of AA between January 2011 and December 2012 were studied retrospectively. The diagnosis of AA was established by medical history, physical examination, white blood cell (WBC) and neutrophil counts, and imaging tests including ultrasonography and abdominal computed tomography. 
Table I. Demographic characteristics of the patients

\begin{tabular}{lccc}
\hline & $\begin{array}{c}\text { Group I } \\
\text { (Negative appendectomy) } \\
\mathbf{n = I ~ I ~}\end{array}$ & $\begin{array}{c}\text { Group II } \\
\text { (Uncomplicated AA) } \\
\mathbf{n = 1 2 2}\end{array}$ & $\begin{array}{c}\text { Group III } \\
\text { (Complicated AA) } \\
\mathbf{n = 2 6}\end{array}$ \\
\hline Age & $22.55 \pm 8.88(8-37)$ & $21.26 \pm 10.25(4-53)$ & $25.42 \pm 13.72(9-57)$ \\
Gender (Male/Female) & $8 / 3$ & $72 / 50$ & $21 / 5$ \\
Nausea & 7 & 60 & 14 \\
Vomiting & 5 & 49 & 9 \\
Fever & 0 & 10 & 4 \\
Tenderness in right lower quadrant & $1 \mathrm{I}$ & 121 & 26 \\
\hline
\end{tabular}

Blood samples were obtained from the patients at the time of admission. Demographic findings, symptoms, signs, WBC and neutrophil counts, surgical procedures, and histopathological results of the appendix examination were recorded. According to the results of histopathological examination of the appendix, patients were divided into 3 groups including Group I with normal appendix (negative appendectomy); Group 2 with uncomplicated inflamed appendicitis (catarrhal and phlegmonous appendicitis); and Group 3 with complicated appendicitis (perforated and gangrenous appendicitis, plastron formation). A positive WBC count was taken as being $>10000$ cells $/ \mathrm{mm}^{3}$. Neutrophil ratio $>70 \%$ was accepted as abnormal. Analysis of the data of total WBC count, neutrophil ratio, and physical findings (rebound tenderness and muscle guarding) was performed. Sensitivities, specificities, positive and negative predictive values of leucocyte count, and neutrophil ratio were calculated.

SPSS 17.0 statistical program was used for statistical analysis. The groups were compared using $t$ test for continuous variables and chi-square test for categorical variables. Mann-Whitney $U$ test was used to compare nonhomogeneous groups in pairs. $P$ value $<0.05$ was considered statistically significant.

\section{RESULTS}

There were one hundred and fifty-nine patients operated with the diagnosis of acute appendicitis in this study. There were one hundred and one male and 58 female patients. The demographic features of all patients were shown in Table $I$.

Simple appendicitis was detected in $82.4 \%$ of the patients and complicated appendicitis in $17.6 \%$ of all patients with acute appendicitis. Leucocyte count had low sensitivity and lower specificity values for diagnosing acute appendicitis $(67.5 \%$ and $36.3 \%$, respectively). On the other hand, neutrophil ratio had a sensitivity rate of $60.1 \%$ and specificity rate of $90.9 \%$ (Table 2 ).

There were no age differences between Groups 2 and 3. Complicated appendicitis was more common in male patients, which was statistically meaningful $(p<0.05)$ (Table 3$)$.
Table 2. The sensitivity, specificity, positive and negative predictive values of WBC count and neutrophil ratio in diagnosing acute appendicitis

\begin{tabular}{lcc}
\hline & WBC count & Neutrophil ratio \\
\hline Sensitivity & $67.5 \%$ & $60.1 \%$ \\
Specificity & $36.3 \%$ & $90.9 \%$ \\
Positive predictive value & 0.93 & 0.97 \\
Negative predictive value & 0.07 & 0.14 \\
\hline
\end{tabular}

WBC: White blood cell.

Table 3. Gender distribution in two groups

\begin{tabular}{|c|c|c|c|c|c|}
\hline & \multicolumn{4}{|c|}{ Patients } & \multirow{3}{*}{$\mathbf{p}$} \\
\hline & \multicolumn{2}{|c|}{$\begin{array}{c}\text { Simple } \\
\text { appendicitis }\end{array}$} & \multicolumn{2}{|c|}{$\begin{array}{l}\text { Complicated } \\
\text { appendicitis }\end{array}$} & \\
\hline & $\mathbf{n}$ & $\%$ & $\mathbf{n}$ & $\%$ & \\
\hline \multicolumn{6}{|l|}{ Gender } \\
\hline Female & 50 & 90.9 & 5 & 9.1 & 0.028 \\
\hline Male & 72 & 77.4 & 21 & 22.6 & \\
\hline Total & 122 & 82.4 & 26 & 17.6 & \\
\hline
\end{tabular}

Table 4. Comparison of two groups according to age, leucocyte, and neutrophil count

\begin{tabular}{lccccccc}
\hline & \multicolumn{4}{c}{ Patients } \\
\cline { 2 - 3 } & \multicolumn{2}{c}{$\begin{array}{c}\text { Simple } \\
\text { appendicitis }\end{array}$} & & \multicolumn{2}{c}{$\begin{array}{c}\text { Complicated } \\
\text { appendicitis }\end{array}$} & p \\
\cline { 2 - 3 } & Mean & SD & & Mean & SD & \\
\cline { 2 - 4 } Age & 21.36 & 10.25 & & 25.42 & 13.72 & 0.338 \\
Leucocyte & $12.257,30$ & $4.609,25$ & & $14.644,62$ & $4.110,15$ & 0.016 \\
Neutrophil & 73.56 & 13.28 & & 76.32 & 17.39 & 0.147 \\
\hline
\end{tabular}

SD: Standard deviation. 


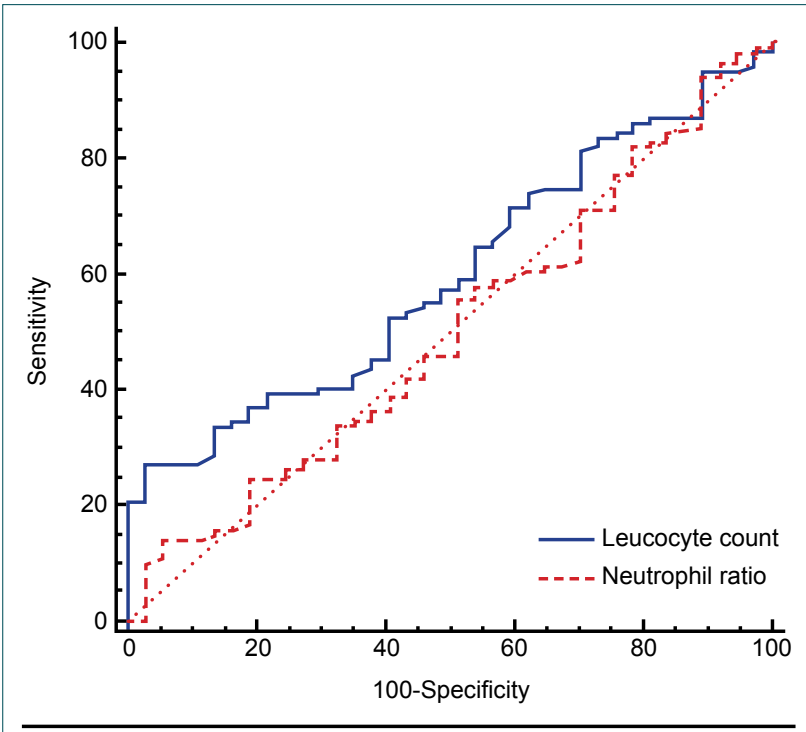

Pairwise comparison of ROC curves

Leucocyte-Neutrophil

Difference between areas

Standard Error

95\% Confidence Interval

z statistic

Significance level

Leucocyte

Neutrophil

Figure 1. ROC curves for leucocyte count and neutrophil ratio.

Leucocyte count was statistically higher in patients with complicated appendicitis $(p<0.05)$. Although neutrophil ratio was higher in complicated appendicitis, the difference was not statistically significant ( $p>0.05$ ) (Table 4). ROC curves for leucocyte count and neutrophil ratio were shown in Figure I. AUC value was 0.596 for leucocyte count and 0.500 for neutrophil ratio. Leucocyte count was found to be a better predictive test for diagnosing acute appendicitis.

\section{DISCUSSION}

Acute appendicitis (AA) is a common surgical problem. About $7.0 \%$ of the general population suffers from appendicitis during their lifetime. It is most commonly encountered in young adults. The diagnosis of acute appendicitis is still a problem even in this modern era. The combination of history, physical examination, laboratory tests, and imaging studies are used for an accurate diagnosis. Several diagnostic tests are used for appendicitis including leucocyte count, neutrophil percentage, C-reactive protein (CRP), D-Dimer, and Procalcitonin. [3-6] However, today, there is no single laboratory test or imaging modality for diagnosing acute appendicitis with $100 \%$ sensitivity.

Leucocyte count is the most frequently used laboratory test in diagnosing appendicitis. It is found easily in every medical center. Moderate leukocytosis $\left(15.000 / \mathrm{mm}^{3}\right)$ is usually the earliest event in the inflammation of the appendix. Leukocyte counts higher than $18.000 / \mathrm{mm}^{3}$ can be related with complicated appendicitis. In several clinical reports, the range of sensitivity and specificity of WBC in the diagnosis of AA have been reported to be $67 \%-97.8 \%$ and $31.9 \%-80 \%$, respectively. ${ }^{[7]}$ In this study, both sensitivity and specificity of leucocyte count was found low for the diagnosis of acute appendicitis, being $67.5 \%$ and $36.3 \%$, respectively. The very low ratio of specificity may be explained by small sample size of the negative appendectomy group.

Neutrophil ratio was also used as a laboratory test for acute appendicitis. In a retrospective study, elevated neutrophil ratio has been detected as a good diagnostic marker in acute appendicitis. The sensitivity of neutrophil ratio has been $60.1 \%$ and specificity $76.9 \%$ in diagnosing acute appendicitis. ${ }^{[8]}$ In the present study, the sensitivity and specificity of neutrophil ratio was found $60.1 \%$ and $90.9 \%$, respectively. According to these results, neutrophil ratio seems to be a better inflammatory marker in acute appendicitis.

Some reports have argued that neutrophil ratio is related with appendicular necrosis and perforation. A neutrophil ratio above $85 \%$ has been associated with advanced appendicular inflammation. ${ }^{[9-11]}$ There was no statistically significant difference in the neutrophil ratio between simple and complicated appendicitis in this study. Therefore, neutrophil ratio was not a proper laboratory test to predict complicated appendicitis.

Al-Gaithy et al. ${ }^{[12]}$ have studied four hundred and fifty-six patients with appendicitis while trying to determine the diagnostic value of leucocyte count and neutrophil ratio and the relation of these inflammatory markers with the severity of acute appendicitis. They have stated that leukocyte and neutrophil counts cannot be used as single diagnostic tests for acute appendicitis. These markers have low sensitivity and specificity. Leucocyte and neutrophil counts do not show the severity of appendicular inflammation, as well. Xharra et

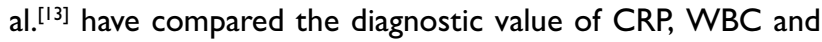
neutrophil count in acute appendicitis. They have reported that the diagnostic value of CRP is not significantly greater than that of WBC and neutrophil and CRP level is directly related to the severity of acute appendicitis. Shafi et al. ${ }^{\left[{ }^{[4]}\right.}$ have studied leucocyte count, neutrophil ratio and CRP level in acute appendicitis. They have indicated that measuring these markers together can increase their specificity and positive predictive value in diagnosing appendicitis.

Complicated appendicitis is associated with perforation, gangrene and intraabdominal abscess formation. The main event to occur in complicated appendicitis is the perforation of the appendix. Thus, the risk factors for appendicular perforation should be reviewed. Barreto SG has studied five hundred and six patients undergoing appendectomy for risk factors causing perforated appendicitis and found that male and old patients over the age of 60 are at significantly increased risk of develop- 
ing perforated appendicitis and a delay in admission to hospital is a second risk factor. ${ }^{[15]}$ Patients presenting after the second day of onset of their symptoms were found to be at significantly increased risk for perforation. Leucocyte count had no statistically significant role for perforated appendicitis. On the other hand, neutrophil count was related with the probability of perforation. CRP levels were also detected as an important marker associated with perforation. Complicated appendicitis rate was higher in male patients in our study. The difference was statistically significant. Leucocyte count was found another parameter associated with complicated appendicitis.

In conclusion, two inflammatory markers, leucocyte count and neutrophil ratio, were evaluated for the diagnosis of acute appendicitis. Neutrophil ratio had higher sensitivity and specificity for acute appendicitis. On the other hand, increased leucocyte count and male gender was found to be a risk factor for complicated appendicitis.

\section{Conflict of interest: None declared.}

\section{REFERENCES}

1. Yang HR, Wang YC, Chung PK, Chen WK, Jeng LB, Chen RJ. Laboratory tests in patients with acute appendicitis. ANZ J Surg 2006;76:71-4.

2. Moraitis D, Kini SU, Annamaneni RK, Zitsman JL. Laparoscopy in complicated pediatric appendicitis. JSLS 2004;8:310-3.

3. Yokoyama S, Takifuji K, Hotta T, Matsuda K, Nasu T, Nakamori M, et al. C-Reactive protein is an independent surgical indication marker for appendicitis: a retrospective study. World J Emerg Surg 2009;4:36. CrossRef

4. Yang HR, Wang YC, Chung PK, Chen WK, Jeng LB, Chen RJ. Role of leukocyte count, neutrophil percentage, and C-reactive protein in the diagnosis of acute appendicitis in the elderly. Am Surg 2005;71:344-7.
5. Sand M, Trullen XV, Bechara FG, Pala XF, Sand D, Landgrafe G, et al. A prospective bicenter study investigating the diagnostic value of procalcitonin in patients with acute appendicitis. Eur Surg Res 2009;43:291-7.

6. Mentes O, Eryilmaz M, Harlak A, Ozer T, Balkan M, Kozak O, et al. Can D-dimer become a new diagnostic parameter for acute appendicitis? Am J Emerg Med 2009;27:765-9. CrossRef

7. Albayrak Y, Albayrak A, Albayrak F, Yildirim R, Aylu B, Uyanik A, et al. Mean platelet volume: a new predictor in confirming acute appendicitis diagnosis. Clin Appl Thromb Hemost 2011;17:362-6. CrossRef

8. Ng KC, Lai SW. Clinical analysis of the related factors in acute appendicitis. Yale J Biol Med 2002;75:41-5.

9. Anderson M, Anderson RE. The appendicitis inflammatory respose score: a tool for the diagnosis of acute appendicitis that outperforms the Alvarado Score. World J Surg 2008;32:1843-9. CrossRef

10. Andersson RE, Hugander AP, Ghazi SH, Ravn H, Offenbartl SK, Nyström PO, et al. Diagnostic value of disease history, clinical presentation, and inflammatory parameters of appendicitis. World J Surg 1999;23:13340. CrossRef

11. Keskek M, Tez M, Yoldas O, Acar A, Akgul O, Gocmen E, et al. Receiver operating characteristic analysis of leukocyte counts in operations for suspected appendicitis. Am J Emerg Med 2008;26:769-72. CrossRef

12. Al-Gaithy ZK. Clinical value of total white blood cells and neutrophil counts in patients with suspected appendicitis: retrospective study. World J Emerg Surg 2012;7:32. CrossRef

13. Xharra S, Gashi-Luci L, Xharra K, Veselaj F, Bicaj B, Sada F, et al. Correlation of serum $\mathrm{C}$-reactive protein, white blood count and neutrophil percentage with histopathology findings in acute appendicitis. World J Emerg Surg 2012;7:27. CrossRef

14. Shafi SM, Afsheen M, Reshi FA. Total leucocyte count, C-reactive protein and neutrophil count: diagnostic aid in acute appendicitis. Saudi J Gastroenterol 2009;15:117-20. CrossRef

15. Barreto SG, Travers E, Thomas T, Mackillop C, Tiong L, Lorimer M, et al. Acute perforated appendicitis: an analysis of risk factors to guide surgical decision making. Indian J Med Sci 2010;64:58-65. CrossRef

\section{KLINIK ÇALIŞMA - ÖZET}

\section{Lökosit sayısı ve nötrofil oranlarının non-komplike apandisit tanısında ve komplike apandisitlerin belirlenmesinde klinik önemi \\ Dr. Nuri Alper Şahbaz, Dr. Orhan Bat, Dr. Bülent Kaya, Dr. Suat Can Ulukent, Dr. Özer İlkgül, Dr. Mehmet Yiğit Özgün, Dr. Özlem Akça}

Kanuni Sultan Süleyman Eğitim ve Araştırma Hastanesi, Genel Cerrahi Kliniği, İstanbul

AMAÇ: Bu çalışmanın amacı komplike olmayan apandisitlerin tanısında ve komplike apandisitlerin belirlenmesinde lökosit sayısı ve nötrofil oranının tanısal değerlerini belirlemektir.

GEREÇ VE YÖNTEM: Bu çalışmada Ocak 20। I ile Aralık 2012 tarihleri arasında akut apandisit tanısıyla apandektomi yapılmış olan hastalar geriye dönük olarak değerlendirildi. Lökosit sayıları, nötrofil yüzdeleri ve fiziksel inceleme bulguları değerlendirildi. Lökosit sayılarının ve nötrofil oranlarının duyarlıık ve özgüllükleri hesaplandı.

BULGULAR: Akut apandisit tanısıyla I59 hasta ameliyat edilmiştir. Hastaların \%82.4'ünde komplike olmayan, \% I7.6'sında komplike apandisit tespit edilmiştir. Lökosit sayısının apandisit tanısında düşük duyarlılık ve özgüllüğünün olduğu görüldü (sırasıyla \%67.5 ve \%36.3). Nötrofil oranının duyarılığı \%60. I, özgüllüğü ise \%90.9 olarak bulundu. Komplike apandisit erkeklerde daha sık görülmektedir. Lökosit sayısı komplike apandisitli hastalarda istatistiksel olarak anlamlı yüksek bulundu.

TARTIŞMA: Akut apandisit tanısında lökosit sayıları ve nötrofil oranları değerlendirilmiştir. Nötrofil oranının daha yüksek duyarlılık ve özgüllüğe sahip olduğu görülmüştür. Aynı zamanda erkek cinsiyetin ve lökosit sayısındaki yüksekliğin komplike apandisit açısından birer risk faktörü olduğu görülmüştür.

Anahtar sözcükler: Apandisit; lökosit; nötrofil.

Ulus Travma Acil Cerrahi Derg 20।4;20(6):423-426 doi: 10.5505/tjtes.20।4.75044 